\title{
Are Spiritual Management and Accountability Able to Improve Village Financial Management for the Better? Case in Sumenep Regency, Indonesia
}

\section{Hafidhah and Mohammad Herli}

Department of Accounting, Economic and Business Faculty, Wiraraja University, Sumenep, Indonesia

\section{Abstract}

The purpose of this study is to examine the influence of spiritual management and accountability in village financial management. We believe that one of the rampant cases of corruption in village finance in Indonesia is due to the lack of religious values from the village head. We did this research in Sumenep Regency because Madura represents the religious community in Indonesia, we determined the village head

Corresponding Author:

Hafidhah

hafidhah@wiraraja.ac.id

Received: 29 January 2019

Accepted: 27 February 2019

Published: 24 March 2019

Publishing services provided by

Knowledge E

(c) Hafidhah and Mohammad

Herli. This article is distributed

under the terms of the Creative

Commons Attribution License,

which permits unrestricted use

and redistribution provided that

the original author and source

are credited.

Selection and Peer-review under the responsibility of the $3 \mathrm{rd}$ ICEEBA Conference Committee. and other village officials as respondents and asked them to fill out a questionnaire, and then analysed using regression. The results show that spiritual management and accountability influence the creation of better village financial management. This implies that the higher values of spirituality and accountability possessed by the village apparatus will improve village financial management toward a better direction. Spiritual values or spiritual values make village officials aware of the importance of good financial management and avoid corruption in village finances. While accountability aspects are essential to be applied at each stage of village financial management.

Keywords: spiritual management, accountability, village finance

Acknowledgments to Wiraraja University as the sponsor for this research

\section{Introduction}

The village is often assumed as an undeveloped area, poor, and traditional. In that case, the role of the government is needed in order to decrease the gap between the city's areas. The definition of the village establishment is to disappear or decreases the obstacles in socio-economic lives; thus are the lack of knowledge, skills, and job opportunities whose citizen of the village live in poverty (T Jayadinata, 1998) 
The existence of law number 6 of 2014 becomes a new hope for village establishment in Indonesia. The village has full authority in doing the management for the establishment of village communities (Herli, 2017). Those authorities are involved in the field of village officials' implementation, village establishment implementation, village fostering community and community empowerment based on village guidelines, the origin rights, and village customisation (law number 6 of 2014).

The important point of the law is the central government takes a role in developing village by using the direct funds from APBN (Aini, 2014). According to the government law of Indonesia number 22 of 2015 verse 30a, the village allocated funds are at least $3 \%$ of APBN, the year of 2016 is $6 \%$ of APBN, and the year of 2017 has increased to $10 \%$ allocation of the APBN total amount for 74,954 villages in Indonesia.

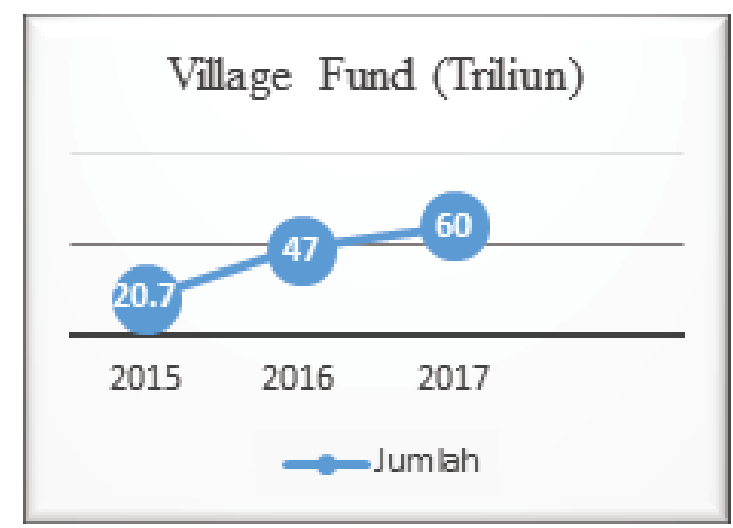

Figure 1: Village Fund Realisation 2015-2017. Source: Ministry of Finance Indonesia.

Based on the above picture, there are enough significant village funds from the year of 2015-2017. On the ledger of APBN 2017, the village fund stock for 2017 reaches 60 trillion rupiah; it increases $27.7 \%$ than the year of 2016 . It means the village receives the fund for about 800 million rupiah on average. If the village receives more from the province/regency/city government, then manageable fund of the village would be 1 billion/year. That high number of amount needs a good management system so it can give the good impact for the establishment in the village (Aziz, 2017). However, what happens now is the amount of the village fund cannot be fully beneficial for the increase of the community's income (Isti, 2017).

The phenomenon happens because of the lack of the village officials understanding toward the good financial management system, so it affects the accountability on the low village financial management (Astuty and Fanida, 2013), thus affects to the low of good local governance in village level (Irma, 2015).

The weak accountability on village financial management system is caused by the many numbers of corruption cases done in the village. Indonesia corruptions watch 
(ICW) has exposed 110 practical corruption cases related to the use of village funds in a time range of 2016 to 2017. It involves 139 practitioners, 107 of them are village heads (Publica News, 2017). One of the cases that attract people attention was the capture of Dasok village head in Pamekasan regency, which also involves the regent of Pamekasan and the chairman of the Pamekasan state court in using the village funds (Kompas, 2017).

The village government can anticipate corruption of the fund if they can represent spiritual values in village financial management. In the context of religion, it is highly forbidden and considered a sinful act. Meaning, the religious dimension is highly correlated with the goal performance on creating the accountability of an organisation (Akir \& Malie, 2012) when it finally could create good governance with principals of; participation, transparency, efficiency, and accountability (Zhu, 2014). Other study found that a leader who applies spiritual principals will tend to do positive things in their works (Lee, Chen, Wang, and Dadura, 2010). In other words, village heads who do the spiritual principals in their lives will likely less avoid the wrongdoings that do not reflect their spiritual beliefs.

This study found that spiritual management has a significant effect toward the increase of village financial management quality to be better. In results, the village heads and other village officials who have high obedience to the religion will embrace the clean financial practice and avoid corruption. This finding is supposed to be an attention to the government to approach spiritually in fostering every village heads and officials.

The accountability aspect also holds an important role in creating the village financial management to be better (Sembiring, Herlinda, \& Ningsih, 2017). The finding of this study also shows that the accountability dimension has also affected to support the fixation of village financial management. For the government to create a village as the centre of the establishment, the accountability aspect must be applied in every part of the village financial management. It must cover all process of village financial management starting from plans, implementations, arrangements, until the report and responsibility.

The contribution of this study is expected to be input on how important the spiritual values are and the accountability in the village financial management system. Furthermore, the village fund could be the main executor for the establishment of the village and the fierce point of fair and expanding national development.

Finally, we step on the structure of this article. After the introduction on the first, the next content of this article is a literature review, the study method, finding, and conclusion on the final part of the article. 


\section{Literature Review}

\subsection{The village financial management}

Village financial management is considered as an effort in supporting the implementation of village governance, implementation of village development, village community development and empowerment of rural communities (Sembiring et al., 2017). Moreover, it is a cycle that consists of planning, budgeting and implementation, administration, reporting and accountability. This cycle is a central-integrated quarter, where one with the other stages is a series. In that case, the stages in village financial management must be done well. If one of the stages, such as planning or administration, experiences problems, then the other stages become disrupted so that the financial management objectives are not in line with the objectives (Wong, Luo, Zhang, and Rozelle, 2013). Therefore, if one stage has a problem, it must be repaired as quickly as possible so that the next stages can go well.

In financial management, the village must strongly hold on to good administrative governance, which embraces participation, accountability, transparency, and justice. The village financial management system would not run well without them. Therefore, other stakeholders outside the village governance and Village Community Board (BPD), such as village figures, religious leaders, the women representatives, farmers representatives, the representatives of the poor, and other communities must be involved in the cycle process of village financial management system. The characteristic of the accountability is expected to not only horizontally connect between village heads and the community, but it must also be vertically connected among village heads, community, camat, and a regent. It is imperative for the documents of the village financial management are accessible to the village community, and not discriminative to a certain group of people.

\subsection{The spiritual management concept and influence toward village financial management}

In a popular scientific dictionary, the definition of management has a meaning as a management, organisation, implementation application of the resource in an effective way to reach the goal (Partanto \& Al Barry, 1994). Management is meant by art in the process of doing plans, organisations, implementations, and controls toward the resource to reach the expected goal (Hani, 2003). So, management is a series of events done in an organisation in order to reach the goal together (Lee et al., 2010). 
The word 'spiritual' can be defined as a word from 'spirit', contains a universal meaning of value that every person must have it without distinguishing any religion (Zohar \& Marshall, 2005). This word has a strong meaning attached to human that reflects the health and prosperity of somebody (Hasan \& Aliah, 2008), it also has an origin characteristic called ilahiyah given to all human on earth. Spirituality is an act to interpreting the divine values on human self, to see one thing deeper as a perspective until they find an authentic truth (Amin, 2010).

From the description above, spiritual management can be interpreted as the actualisation of spiritual values in management. The management pattern which consists of planning, organising, actuating, and controlling in the context of spiritual management must be integrated with divine values so that the desired goal is not only achieved in a worldly state that justifies any means necessarily. In other words, the operating people in management integrate the spiritual intelligence in management patterns and sequences. Spiritual intelligence is a human ability to understand high values and meanings and the true purpose of human life (Agustian, 2009). Spiritual management consists of three main aspects, namely the inner life, meaningful work, and community (Ashmos \& Duchon, 2000).

The inner life as spiritual identity, spiritual condition of their leader, meaning the feeling individuals have about the fundamental meaning of who they are, what there are doing, contributions the are making.

From the quote above, it is understandable that inner life has been a component in spiritual management, it is an inner life as a spiritual identity, it is an individual feeling about the basic meaning of who they are, why they exist, and what contribution is being made.

Meaningful work, all work is a vocation, a calling from a place that is the source of meaning and identity, the root of which lies beyond human intention and interpretation.

Meaningful work means a job that has value and a call that outruns everything.

Community, spirituality at work has appeared in part because people want to feel connected to work that is important, and they want to feel connected to each other at work. It means Community is a place for people to feel the bond at each other.

The principles implementation of spiritual management in financial management will encourage the Village Head and other Village officials to work wholeheartedly by emphasising the needs of the village community (Setianingsih, 2012). The concept of inner life in a component of spiritual management will create awareness to the village administrators to develop focuses on the welfare of the community. This means that when these principles are implemented in village financial management, it will create 
good village financial management in accordance with the divine values they believe in (Teng, 2011). An empirical study on the influence of the principles of spirituality toward performance has been carried out, and it is proven significantly to improving the work performance (Trihandini, 2005).

H1: the spiritual management affects positively toward the fixation of village financial management.

\subsection{The accountability concept and connection related to village funds}

Accountability is a form of responsibility for the success or failure of an organisation's mission to achieve the desired goals through a media of accountability carried out periodically (Mardiasmo, 2002). Accountability in village financial management can be interpreted as responsibility for financial revenues and expenditures in order to obtain reliable and trusted financial statements.

Accountability, in this case, is public financial accountability, namely accountability in village financial management. There are several dimensions of accountability as mentioned by Ellwood (Ellwood, 1993), namely:

1. The law and honesty accountability

The accountability that closely relates to the avoidance of office position and guarantees, the existence of legal compliance, namely the responsibility of the public institution to behave honestly in work and comply with the applicable legal provisions.

2. The managerial accountability

It is a responsibility of the public institutions to practice managerial organisations effectively and efficiently which also can be interpreted as performance accountability. This accountability also relates with the process accountability, meaning that the organisation process must be accountable. In other words, there no inefficiency and inactiveness of organisations

3. The program accountability

This accountability closely relates to the determined purposes whether it is reachable or not, and the organisation that has concerned about the alternative programs with optimal results.

4. The policy accountability 
This is related to the accountability of policies taken by public institutions. Public institutions should be able to account for policies that have been established by considering the impact in the future.

5. The financial accountability

This is related to the accountability of public institutions to use people's money economically, efficiently and effectively, there is no waste and leakage of funds and corruption. Financial accountability is very important because the public management finances will be the main concern of the community. Financial accountability requires an institution to make reports that describe the organisation's performance to the community.

The correlation between the principals of accountability and village financial management is the responsibility of the village heads in implementing the governance and fund use in a certain period. If the village governance applied the principals of accountability, it would create an efficiency \& effectiveness on the establishment of a village. It means that the accountability that is applied in a village will create a good financial report. In other words, the accountability affects toward the creation of good village financial management ( Jitmau, Kalangi, and Lambey, 2017).

H2. The accountability affects toward the fixation of village financial management.

\section{Research Method}

\subsection{Research design}

This research is an empirical study conducted to prove the influence of spiritual management and accountability on financial management in the village. For this reason, the approach is to use a quantitative approach. The population in this study is all Village Heads in Sumenep Regency. Meanwhile, the data collection is done by distributing questionnaires to the Village Head as the sample of the study, conducting interviews, and making observations to the subjects who become the respondents of this study.

Because of the vast population in this study, the sample is determined intentionally. This means that the researcher intentionally occupies the village whose village heads will be used as a research sample. The sample in this study will be focused on three main criteria, namely villages in urban, suburb and remote areas not including villages in the outer islands. With these criteria, the sample is a village located in the Districts of Kota Sumenep, Batuan, Lenteng, and Dasuk, with total number to approximately 80 
villages. In the end, we managed to collect as many as 84 respondents for the purposes of this study.

\subsection{Variable and operational variable}

Independent variables are variables that affect the dependent variable in positive or negative elements (See appendix 1). In this study, the independent variable consists of two variables, namely Spiritual management variable (X1) and Accountability variable (X2). Dependent variables are variables that are affected or being a result caused by the independent variables. The dependent variable in this study is financial management symbolised by (Y).

\subsection{Data analysis technique}

Data analysis used in this study is Multiple Linear Regression (MLR) which will be tested before for the validity and reliability of the instruments used. To test the research hypothesis, the t-test will be conducted.

\section{Result and Discussion}

This research was conducted to acknowledge the influence of the spiritual management and accountability in village financial management in Sumenep Regency. We use the data in form of questionnaires and distribute to all village officials. We performed an analysis of the questionnaire to see the impact of the independent variables toward the dependent variable that we proposed in this study. In this section, we will analyse the respondents and then the validity and reliability of the data, and discuss and draw conclusions of the research data.

\subsection{Respondents identities}

\subsubsection{Sex of respondents}

Based on the research data, males are dominating with $83 \%$ while $17 \%$ are females. 
TABLE 1: Sex of respondents.

\begin{tabular}{|l|l|c|c|c|}
\hline No. & Sex & Total & $\%$ \\
\hline 1 & Male & 70 & 83 \\
\hline 2 & Female & 14 & 17 \\
\hline Total & & 84 & 100 \\
\hline
\end{tabular}

\subsubsection{Age of respondents}

It is based on the age of all village officials who fill out the questionnaire forms.

TABLE 2: Age of respondents.

\begin{tabular}{l|l|c|c|} 
No. & Age & Total & $\%$ \\
\hline 1 & 21 y.o -30 y.o & 13 & 15.48 \\
\hline 2 & 31 y.o -40 y.o & 24 & 30.95 \\
\hline 3 & 41 y.o -50 y.o & 36 & 40.48 \\
\hline 4 & $>50$ y.o & 11 & 13.10 \\
\hline Total & & 84 & 100 \\
\hline
\end{tabular}

According to this research, the age of respondents consists of four main parts, the age of 21 to 30 is $15.48 \%, 31$ to 40 is $30.95 \%, 41$ to 50 is $40.48 \%$, and the rest is the respondents with the age of more than 50 are $12.10 \%$. Table 2 shows that village officials are approximately in productive age.

\subsubsection{Education of respondents}

In this study, the level of education is the last formal education of the respondents; the details are in the following:

TABLE 3: The level of education of respondents.

\begin{tabular}{|l|l|c|c|}
\hline No. & Education level & Sum & $\%$ \\
\hline 1 & Unfinished elementary school & 1 & 1.2 \\
\hline 2 & SMP (Junior High School) & 4 & 4.8 \\
\hline 3 & SLTA (Senior High School) & 54 & 64.3 \\
\hline 4 & S1 (Bachelor degree) & 22 & 26.2 \\
\hline 5 & S2 (Master degree) & 3 & 3.6 \\
\hline Total & & 84 & 100 \\
\hline
\end{tabular}

Based on the table above, the most respondents are educated with the level of high school students for $64.3 \%$. Some bachelor students are $26.2 \%$, and master students are $3.6 \%$. Table 3 shows that the village officials are only graduates of senior or even junior high school. This should be a concern for the government to set the requirements of 
village officials' minimum for graduates are bachelor degree. This policy is essentially important to help the development of village management and finance.

\subsubsection{Work position of respondents}

The work position of the respondents is a job that they hold on to when filling out the questionnaire. It is village heads, village secretary, implementation heads and so on.

TABLE 4: The work position of respondents.

\begin{tabular}{l|l|}
\hline No & work position \\
\hline 1 & Village head \\
2 & Village secretary \\
3 & Village treasury \\
\hline 4 & Implementation head \\
\hline 5 & Sub-village heads \\
6 & BPD member \\
\hline 5 & Other \\
\hline Total &
\end{tabular}

\begin{tabular}{|c|c|}
\hline Total & $\%$ \\
\hline 33 & 39.3 \\
\hline 14 & 16.7 \\
\hline 6 & 7.1 \\
\hline 11 & 13.1 \\
\hline 12 & 14.3 \\
\hline 5 & 6.0 \\
\hline 3 & 3.6 \\
\hline 84 & 100 \\
\hline
\end{tabular}

Based on the data above, we can know the identity of the respondents in the accordance of the work position, whereas village heads are $39.3 \%$ of the major respondents, village secretary is $16.7 \%$, the sub-village heads is $14.3 \%$, the implementation heads is $13.1 \%$, village treasury is $13.1 \%$, BPD member and other position for 6 and $3.6 \%$.

\subsubsection{Work/position period}

The working period is measured from the first time in taking an occupation as village officials. In Table 5 below shows the respondents' identity based on their work period.

TABLE 5: The work/position period.

\begin{tabular}{|l|c|c|c|}
\hline No. & The work period & Total & $\%$ \\
\hline 1 & $1-5$ years & 59 & 70.2 \\
\hline 2 & $6-10$ years & 23 & 27.4 \\
\hline 3 & $>10$ years & 2 & 2.4 \\
\hline Total & & 84 & 100 \\
\hline
\end{tabular}

As we can see from the table above, the majority of the respondents are between 1-5 years for $70.2 \%$, and the rest of $27.4 \%$ respondents are at $6-10$ years period of working. There are only a small number of respondents who have more than ten years of work period for $2.4 \%$. 


\subsection{The data quality test}

This procedure was done by conducting the instrument validity test; it aims to know whether questionnaire could measure the researched variable precisely or not. A questionnaire is indicated valid if questions of a questionnaire could reveal something measured by it. A data/questionnaire can be said whether it is valid or not, could be seen on how high value of $r$ count. The correlation count result of the product moment as seen on appendix 1 indicates that all variables are valid except for instrument X.1.3 because it is less than $r$ table to be valid, then we issued it as an instrument.

Next, we did a reliability test. Reliability is an index which points on how far the measurement tool can be trusted and reliable. An instrument can be said reliable if it has main coefficient reliability of 0.6 or more. The reliability test of this study is done by using Alpha Cronbach. If alpha is less than 0.6, then it is declared reliable. The Alpha Cronbach calculation results on each item in the organisational culture variable (X1) have a greater value than the limit of Alpha minimum of 0.6. Thus it can be concluded that the variable item of this questionnaire is reliable.

\subsection{The regression analysis}

The regression test is used to see the influence of the independent variables, which are the spiritual management variable and accountability toward a dependent variable. Thus it is village financial management. The results of the regression test can be observed from Table 6 below.

TABLE 6: The regression analysis.

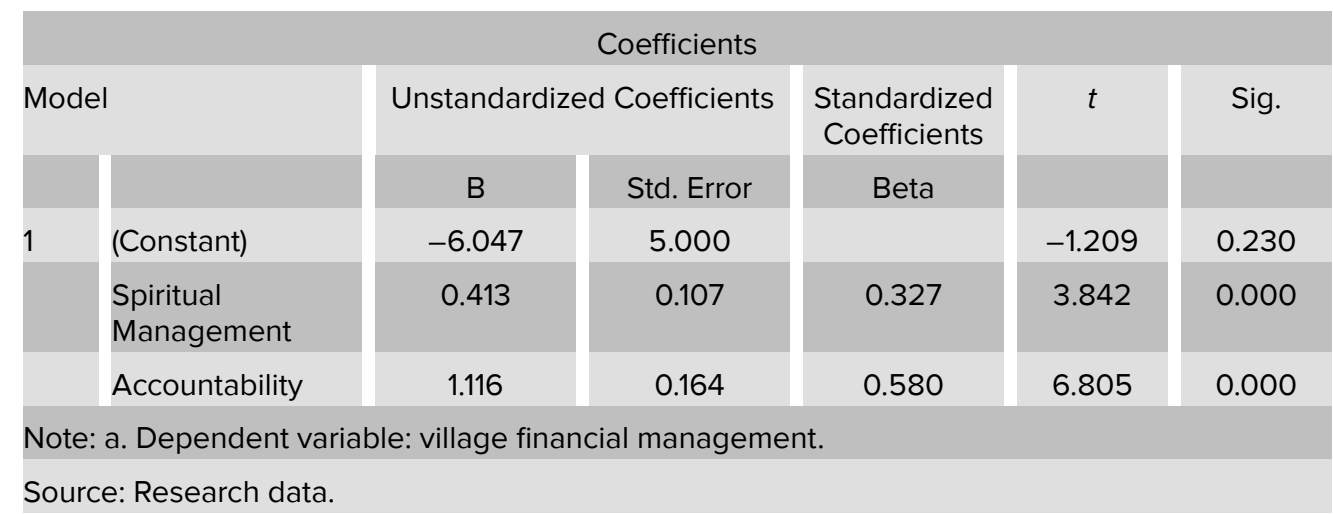

This analysis is used to calculate the great value of the relations between the independent variable and the dependent variable, through the relations of $X 1$ and $X 2$ to $Y$. The 
regression model based on the results of the existing analysis is as follows, assuming that other variables besides the independent variables in this study are constant.

From the analysis of the Multi-Regression analysis above, it can be seen the closeness of the relations between spiritual management (Variable X1) and accountability (Variable X2) with village financial management (Variable Y). From the SPSS output in Table 6, the regression equation is stated as follows:

$$
Y=-6.047+0.413 X_{1}+1.116 X_{2}+e .
$$

From the regression equation above, it can be seen that the negative multiple regression constancy means that if the independent variable is in an instance, the village financial management will be valued negatively. While the coefficient regression of b1 and $b 2 \mathrm{~d}$ are positive, meaning that the components of the independent variable are giving a strong reaction in village financial management.

There are different influences between spiritual management and accountability variables, where the accountability variable has more significant influence on the value of village financial management compared to spiritual management variables.

According to Table 7 below, the value of $F$ test shows significant results. This means the model can explain the relations between dependent and independent variables.

TABLE 7: F-test.

\begin{tabular}{|c|c|c|c|c|c|c|}
\hline \multicolumn{7}{|c|}{ ANOVA } \\
\hline \multicolumn{2}{|c|}{ Model } & \multirow{2}{*}{$\begin{array}{c}\text { Sum of } \\
\text { Squares } \\
2265.387\end{array}$} & \multirow{2}{*}{$\begin{array}{l}\mathrm{df} \\
2\end{array}$} & \multirow{2}{*}{$\begin{array}{c}\text { Mean Square } \\
1132.694\end{array}$} & \multirow{2}{*}{$\begin{array}{c}F \\
102.825\end{array}$} & \multirow{2}{*}{$\begin{array}{c}\text { Sig. } \\
0.000^{b}\end{array}$} \\
\hline 1 & Regression & & & & & \\
\hline & Residual & 892.279 & 81 & 11.016 & & \\
\hline & Total & 3157.667 & 83 & & & \\
\hline
\end{tabular}

Table 8 below displays the coefficient determination test (R2), it appears that the R2 test results are quite high at 0.71 . This shows that this variable can explain about $71 \%$ while the rest is explained by other variables.

TABLE 8: Coefficient determination test.

\begin{tabular}{|c|c|c|c|c|c|}
\hline \multicolumn{6}{|c|}{ Model Summary ${ }^{b}$} \\
\hline Model & $\mathrm{R}$ & R Square & $\begin{array}{l}\text { Adjusted R } \\
\text { Square }\end{array}$ & $\begin{array}{l}\text { Std. Error of } \\
\text { the Estimate }\end{array}$ & Durbin-Watson \\
\hline 1 & $0.847^{a}$ & 0.717 & 0.710 & 3.31900 & 1.838 \\
\hline
\end{tabular}




\section{Discussion}

\subsection{The effect of spiritual management on village financial management}

The statistical output indicates the existence of significant influence between spiritual management and village financial management. This means, our hypothesis stating that spiritual management affects toward the village financial management is true. This finding explains that a good village financial management involves the spiritual elements of the village in planning, implementing, and taking responsibility for village finances. The higher spiritual values used in village financial management, the better financial management in the village will be.

The use of these spiritual values is very important to be carried out by village officials to avoid fraud 'corruption' in village finance. The existence of these spiritual values will be able to prevent village officials from taking actions that inflict financial loss on village finances. Believing in God will increase awareness of village officials to avoid actions that violate spiritual rules (religion), including corruption behaviour against village finances.

\subsection{The effect of accountability on village financial management}

The variable of accountability is the second variable that shows a significant value. It shows that accountability also influences the creation of good village financial management. The interesting thing is, this variable is dominant enough to create good village financial management compared to spiritual management variables.

Accountability in village financial statements is not only limited to the reporting stage, but it covers all aspects of the planning, implementation, administration, reporting, and accountability processes. All these stages require accountability to produce good village financial management. A village financial management that begins with the planning process needs to apply the concepts of accountability in the budgeting process and the making of the Budget Plan for the next year. So do the process of implementing village finances and other processes. The important role of accountability in colouring all aspects of village financial management will strongly encourage creating better and more accountable village finance as mandated by the government through the law. 


\section{Conclusion}

This study was conducted to examine the influence of management spiritual variables and accountability on village financial management. We believe that the rampant corruption that occurs in village finance is caused by one of the factors of the village administrators who have abandoned spiritual values in village financial management. We also believe, in order to create improvements in village financial management, it is necessarily needed to pay attention to the dimensions of accountability in each stage and process of village financial management.

The research finding indicates that the spiritual values possessed by the village administrators can create better village financial management. It also indicates that the higher values of spirituality will improve the village financial management to a better direction. Thus, the government needs to pay attention to aspects of spirituality by guiding village officials.

Accountability also has a significant influence in creating better village finance. The relation formed between both of them is positive and similar; this indicates that the stronger accountability dimension in village financial management is the better village finances will be. Another finding is the high coefficient of determination; this shows that the variables used in this study can explain the model very well.

We might have limitations in this research to be corrected in future research. Limitations in the number of samples and the possibility of other variables that need to be focused on village financial management, for example, aspects of supervision may be a concern for further research.

\section{References}

[1] Agustian, A. G. (2009). ESQ Emotional Spiritual Quotient: The Esq Way 165; 1 Ihsan, 6 Rukun Iman Dan 5 Rukun Islam. ESQ Leadership Center Sdn. Bhd.

[2] Akir, O. and Malie, S. (2012). Integrity dimensions and religious orientation in aspect of employees job conduct: an exploratory model building. Procedia-Social and Behavioral Sciences, vol. 62, pp. 167-174.

[3] Amin, A. R. (2010). Initiating Sharia Management (The Celestial Management Theory and Practice). Jakarta: Salemba Empat.

[4] Ashmos, D. P. and Duchon, D. (2000). Spirituality at work: A conceptualization and measure. Journal of Management Inquiry, vol. 9, no. 2, pp. 134-145. 
[5] Astuty, E. and Fanida, E. H. (2013). Village Government Accountability in Managing Village Budget (APBDES) (Study on Village Fund Allocation in Fiscal Year 2011 in Sareng Village, Geger District, Madiun Regency). E-Journal Unesa, vol. 1, no. 2.

[6] Aziz, N. L. (2017). Village autonomy and the effectiveness of village funds. Jurnal Penelitian Politik, vol. 13, no. 2, pp. 193-211.

[7] Ellwood, S. (1993). Parish and town councils: Financial accountability and management. Local Government Studies, vol. 19, no. 3, pp. 368-386.

[8] Hani, H. T. (2003). Management. Yogyakarta: BPFE-Yogyakarta.

[9] Hasan, A. B. P. and Aliah, B. (2008). Islamic Development Psychology: Revealing the Range of Human Life from Pre-birth to Post-Death. Rajagrafindo.

[10] Herli, M. (2017). The role of community supervision on village financial management to make financial accountability in the village. PERFORMANCE: Jurnal Bisnis \& Akuntansi, vol. 7, no. 1, pp. 43-52.

[11] Irma, A. (2015). Village Fund Allocation Management Accountability (ADD) in South Dolo District, Sigi Regency. Katalogis, vol. 3, no. 1.

[12] Isti, D. N. (2017). Perception and community participation on the use of village funds for empowerment of communities in kertajaya village, kecamatan padalarang, bandung barat regency. Jurnal Pendidikan Luar Sekolah, vol. 13, no. 1.

[13] Jitmau, F., Kalangi, L., and Lambey, L. (2017). Effect of accountability, transparency and function of internal examination on local government performance (empirical study in Sorong district). Jurnal Riset Akuntansi dan Auditing "Goodwill", vol. 8, no. 1.

[14] Lee, T.-R., Chen, S.-Y., Wang, S.-H., et al. (2010). The relationship between spiritual management and determinants of turnover intention. European Business Review, vol. 22 , no. 1, pp. 102-116.

[15] Mardiasmo, D. (2002). Public Sector Accounting. Yoyakarta: Andi Offiset.

[16] Partanto, P. A. and Al Barry, M. D. (1994). Kamus ilmiah populer. Surabaya: Arkola, vol. 37, p. 23.

[17] Sembiring, R., Herlinda, E., and Ningsih, S. (2017). Implementation of autonomy area through the implementation of village authority. International Journal of Economic Perspectives, vol. 11, no. 3, pp. 5-11.

[18] Setianingsih, S. (2012). A study on teaching-learning activities on science at Smp AlIslam Surakarta School designed for international standard in 2011/2012 academic year. PhD Thesis, Universitas Muhammadiyah Surakarta.

[19] T Jayadinata, J. (1998). Village Development in Planning. 
[20] Teng, S.-N. (2011). Analyzing the application of computer in Chinese rural financial management, in BMEI - Proc. Int. Conf. Bus. Manage. Electron. Inf, vol. 2, pp. 268270. Retrieved from: https://doi.org/10.1109//CBMEl.2011.5917897

[21] Trihandini, R. F. M. (2005). Analysis of the effect of intellectual intelligence, emotional intelligence, and spiritual intelligence on employee performance (case study at Horison Hotel Semarang). PhD Thesis, Program Pascasarjana Universitas Diponegoro.

[22] Wong, H. L., Luo, R., Zhang, L., et al. (2013). Providing quality infrastructure in rural villages: The case of rural roads in China. Journal of Development Economics, vol. 103, no. 1, pp. 262-274. Retrieved from: https://doi.org/10.1016/j.jdeveco.2013.03.002

[23] Zhu, Y. Y. (2014). The innovation research of rural accounting agency system under urban and rural overall energy environment. Energy Education Science and Technology Part A: Energy Science and Research, vol. 32, no. 6, pp. 6843-6848.

[24] Zohar, D. and Marshall, I. (2005). Spiritual Capital: Empower SQ in the Business World. Mizan.

[25] Law Number 6, 2014.

[26] Government law of Indonesia Number 22, 2015.

[27] Law of Home State Affairs Number 113, 2014.

[28] Law of Home State Affairs Number 114, 2014.

[29] Government law Number 43, 2015.

\section{Appendix A}

\section{A.1. Operational variable definition: \\ Variable, operational variable, indicator, scale}

\section{A.2. Validity Test Instrument}

\section{A.3. Reliability Test Instrument}




\begin{tabular}{|c|c|c|c|c|}
\hline No. & Variables & Dimension & Indicators & Scale \\
\hline \multirow[t]{3}{*}{1} & $\begin{array}{l}\text { Spiritual } \\
\text { Management }\end{array}$ & Inner Life & $\begin{array}{l}\text { Having a high expectation in life. Spiritual } \\
\text { values The importance of prayer in } \\
\text { everyday life Aware of what self-meaning } \\
\text { is Care about the spiritual health }\end{array}$ & Ordinal \\
\hline & & Meaningful work & $\begin{array}{l}\text { Happy with the job Trust the feedbacks } \\
\text { from others. Responsible at work Having } \\
\text { the strong will Aware of the importance } \\
\text { of work with social fixation }\end{array}$ & \\
\hline & & Community & $\begin{array}{l}\text { Being a part of organizations Happy to } \\
\text { motivate Discuss with a colleague when } \\
\text { the problem exists Love to do a team } \\
\text { work Appreciate others }\end{array}$ & \\
\hline \multirow[t]{5}{*}{2} & Accountability & Law and Honesty & $\begin{array}{l}\text { Not misusing the work position Obey to } \\
\text { the applicable rules }\end{array}$ & Ordinal \\
\hline & & Managerial & $\begin{array}{l}\text { Implementing the management of } \\
\text { organization efficiently and effectively } \\
\text { Responsible for the process of } \\
\text { organisations }\end{array}$ & \\
\hline & & Program & $\begin{array}{l}\text { Achievement of the implemented } \\
\text { programs }\end{array}$ & \\
\hline & & Policy & Responsible for policies & \\
\hline & & Financial & $\begin{array}{l}\text { Efficient use of finance Good and } \\
\text { temporary report }\end{array}$ & \\
\hline \multirow[t]{4}{*}{3} & $\begin{array}{l}\text { Financial } \\
\text { management }\end{array}$ & Planning & $\begin{array}{l}\text { Involvement of all parties Village } \\
\text { planning is made by taking into the } \\
\text { profile and potential of the village } \\
\text { Alignment with the direction of } \\
\text { district/city development Evaluation } \\
\text { Made by referring to existing rules }\end{array}$ & Ordinal \\
\hline & & Implementing & $\begin{array}{l}\text { Procedure of receiving and spending in } \\
\text { one village cash account Existence of } \\
\text { evidence The principle of efficiency and } \\
\text { efficient Supervision }\end{array}$ & \\
\hline & & Administrating & $\begin{array}{l}\text { Well done and right Document availability } \\
\text { The compliance of rules }\end{array}$ & \\
\hline & & $\begin{array}{l}\text { Reporting and } \\
\text { accountability }\end{array}$ & $\begin{array}{l}\text { Compliance in reporting Document } \\
\text { availability Openness Compliance }\end{array}$ & \\
\hline
\end{tabular}




\begin{tabular}{|c|c|c|c|c|}
\hline Variable & Item & R-Count & R-Table & Note \\
\hline \multirow[t]{15}{*}{ Spiritual management (X1) } & $\mathrm{X} 1.1$ & 0.298 & 0.212 & Valid \\
\hline & $\mathrm{X} 1.2$ & 0.385 & 0.212 & Valid \\
\hline & $X 1.3$ & 0.122 & 0.212 & Invalid \\
\hline & $\mathrm{X} 1.4$ & 0.548 & 0.212 & Valid \\
\hline & X1.5 & 0.599 & 0.212 & Valid \\
\hline & $\mathrm{X} 1.6$ & 0.608 & 0.212 & Valid \\
\hline & $\times 1.7$ & 0.581 & 0.212 & Valid \\
\hline & $\mathrm{X} 1.8$ & 0.428 & 0.212 & Valid \\
\hline & $\times 1.9$ & 0.614 & 0.212 & Valid \\
\hline & $X 1.10$ & 0.512 & 0.212 & Valid \\
\hline & X1.11 & 0.523 & 0.212 & Valid \\
\hline & $\mathrm{X} 1.12$ & 0.587 & 0.212 & Valid \\
\hline & X1.13 & 0.527 & 0.212 & Valid \\
\hline & $\mathrm{X} 1.14$ & 0.631 & 0.212 & Valid \\
\hline & $\times 1.15$ & 0.365 & 0.212 & Valid \\
\hline \multirow[t]{8}{*}{ Accountabilities (X2) } & $\times 2.1$ & 0.626 & 0.212 & Valid \\
\hline & $\times 2.2$ & 0.725 & 0.212 & Valid \\
\hline & $\times 2.3$ & 0.794 & 0.212 & Valid \\
\hline & $\times 2.4$ & 0.686 & 0.212 & Valid \\
\hline & $\times 2.5$ & 0.725 & 0.212 & Valid \\
\hline & $\times 2.6$ & 0.723 & 0.212 & Valid \\
\hline & $\times 2.7$ & 0.672 & 0.212 & Valid \\
\hline & $\times 2.8$ & 0.703 & 0.212 & Valid \\
\hline \multirow[t]{14}{*}{ Village financial management $(Y)$} & Y1.1 & 0.605 & 0.212 & Valid \\
\hline & Y1.2 & 0.633 & 0.212 & Valid \\
\hline & Y1.3 & 0.524 & 0.212 & Valid \\
\hline & Y1.4 & 0.755 & 0.212 & Valid \\
\hline & Y1.5 & 0.765 & 0.212 & Valid \\
\hline & Y1.6 & 0.769 & 0.212 & Valid \\
\hline & Y1.7 & 0.684 & 0.212 & Valid \\
\hline & Y1.8 & 0.614 & 0.212 & Valid \\
\hline & Y1.9 & 0.725 & 0.212 & Valid \\
\hline & Y1.10 & 0.706 & 0.212 & Valid \\
\hline & Y1.11 & 0.689 & 0.212 & Valid \\
\hline & Y1.12 & 0.681 & 0.212 & Valid \\
\hline & Y1.13 & 0.752 & 0.212 & Valid \\
\hline & Y1.14 & 0.726 & 0.212 & Valid \\
\hline \multicolumn{2}{|l|}{ Variable } & Value & Note & \\
\hline \multicolumn{2}{|c|}{ Spiritual management (X1) } & 0.911 & Reliable & \\
\hline \multicolumn{2}{|c|}{ Accountabilities (X2) } & 0.852 & Reliable & \\
\hline \multicolumn{2}{|c|}{ Village financial management $(\mathrm{Y})$} & 0.784 & Reliable & \\
\hline
\end{tabular}

